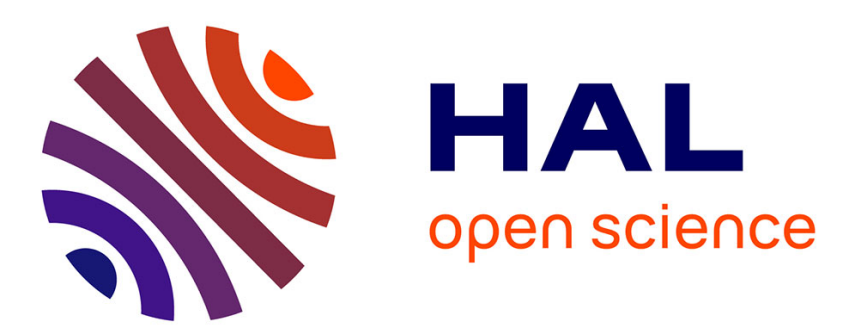

\title{
Low-Temperature Interface Reaction between Titanium and the Eutectic Silver-Copper Brazing Alloy
}

\author{
J. Andrieux, Olivier Dezellus, F. Bosselet, J.C. Viala
}

\section{To cite this version:}

J. Andrieux, Olivier Dezellus, F. Bosselet, J.C. Viala. Low-Temperature Interface Reaction between Titanium and the Eutectic Silver-Copper Brazing Alloy. Journal of Phase Equilibria and Diffusion, 2009, 30 (1), pp.40-45. 10.1007/s11669-008-9424-7 . hal-00422608

\section{HAL Id: hal-00422608 \\ https://hal.science/hal-00422608}

Submitted on 7 Oct 2009

HAL is a multi-disciplinary open access archive for the deposit and dissemination of scientific research documents, whether they are published or not. The documents may come from teaching and research institutions in France or abroad, or from public or private research centers.
L'archive ouverte pluridisciplinaire HAL, est destinée au dépôt et à la diffusion de documents scientifiques de niveau recherche, publiés ou non, émanant des établissements d'enseignement et de recherche français ou étrangers, des laboratoires publics ou privés. 


\title{
Low-Temperature Interface Reaction between Titanium and the Eutectic Silver-Copper Brazing Alloy
}

\author{
J. Andrieux, O. Dezellus, F. Bosselet, J.C. Viala* \\ Laboratoire des Multimatériaux et Interfaces, LMI, UMR CNRS 5615, Université Claude \\ Bernard Lyon 1, 69622 Villeurbanne Cedex (France)
}

\begin{abstract}
Reaction zones formed at $790{ }^{\circ} \mathrm{C}$ between solid titanium and liquid $\mathrm{Ag}$-Cu eutectic alloys (pure and Ti-saturated) have been characterized. When pure $\mathrm{Ag}-\mathrm{Cu}$ eutectic alloy with 40 at. $\% \mathrm{Cu}$ is used, the interface reaction layer sequence is: $\alpha \mathrm{Ti} / \mathrm{Ti} 2 \mathrm{Cu} / \mathrm{TiCu} / \mathrm{Ti}_{3} \mathrm{Cu}_{4} / \mathrm{TiCu}_{4} /$ $\mathrm{L}$. Because of the fast dissolution rate of $\mathrm{Ti}$ in the alloy, the reaction zone remains very thin (3-6 $\mu \mathrm{m})$ whatever the reaction time. When the $\mathrm{Ag}-\mathrm{Cu}$ eutectic alloy is saturated in titanium, dissolution no longer proceeds and a thicker reaction zone with a more complex layer sequence grows as the reaction time increases. Four elementary chemical interaction processes have been identified in addition to Ti dissolution in the liquid alloy. These are growth of reaction layers on Ti by solid state diffusion, nucleation and growth from the liquid of $\mathrm{TiCu}_{4}$, isothermal solidification of silver and, finally, chemical conversion of the Cu-Ti compounds by reaction-diffusion in the solid state. A mechanism combining these processes is proposed to account for the constitution of $\mathrm{Ti} / \mathrm{Ag}-\mathrm{Cu} / \mathrm{Ti}$ joints brazed at $780-800{ }^{\circ} \mathrm{C}$.
\end{abstract}

Keywords: metals; intermetallics; diffusion paths; chemical potential gradients; ternary system

\section{Introduction}

The Ag-Cu eutectic alloy with 40 at. $\% \mathrm{Cu}(28 \mathrm{wt} . \% \mathrm{Cu})$ has already shown good wetting and bonding characteristics with regard to conventional brazing of titanium parts at temperatures higher than $850{ }^{\circ} \mathrm{C}$ [1]. This behaviour is explained by the formation of binary Ti-Cu compounds that promote reactive wetting and spreading at the liquid/solid interface [1-4]. Surprisingly, data are very scarce about brazing of titanium parts at temperatures lower than $850{ }^{\circ} \mathrm{C}$, although promising observations have been made [3]. In fact, operating at temperatures closer to the melting point of the alloy (which is of $780{ }^{\circ} \mathrm{C}$ ) should be favourable to the preservation of the microstructure and composition of the titanium base metal. Moreover, formation of copper-rich Ti-Cu solid compounds should render possible isothermal solidification of the Ag-Cu brazing alloy. In other words, the development of a process for brazing titanium or titanium alloys by transient liquid phase bonding at low temperature should be very attractive from an applied perspective [5, 6]. For these reasons, it was decided to further investigate the chemical interaction between titanium and the eutectic $\mathrm{Ag}-\mathrm{Cu}$ alloy at temperatures down to $780{ }^{\circ} \mathrm{C}$, the temperature of the eutectic transformation.

In the first approach at investigating the kinetics of compound formation in the $\mathrm{Ag}-\mathrm{Cu}-\mathrm{Ti}$ system, cold-pressed mixtures of $\mathrm{Ag}, \mathrm{Cu}$ and $\mathrm{Ti}$ powders were heated at $700-860{ }^{\circ} \mathrm{C}$ and characterized [7]. In the present work, additional experiments have been carried out at 780$800{ }^{\circ} \mathrm{C}$ on $\mathrm{Ti} / \mathrm{Ag}-\mathrm{Cu}$ semi infinite couples and $\mathrm{Ti} / \mathrm{Ag}-\mathrm{Cu} / \mathrm{Ti}$ sandwiches in order to determine the extent and constitution of the interface reaction zone formed between solid Ti and liquid $\mathrm{Ag}-\mathrm{Cu}$ eutectic alloy. 


\section{Experimental}

Experiments on $\mathrm{Ti} / \mathrm{Ag}-\mathrm{Cu}$ couples were performed in the sessile drop configuration. On the one hand, a pure binary $\mathrm{Ag}-\mathrm{Cu}$ eutectic alloy (40 at.\% $\mathrm{Cu}$ ) without $\mathrm{Ti}$ was used; on the other hand, 1.88 at.\% of $\mathrm{Ti}(1 \mathrm{wt} . \%)$ was added so that the Ag-Cu alloy was slightly oversaturated in $\mathrm{Ti}$ at $790{ }^{\circ} \mathrm{C}$ according to [8]. In both cases, the quantities used were such that the composition of the liquid remained as constant as possible. For that purpose, small blocks of $\mathrm{Ag}-\mathrm{Cu}$ or $\mathrm{Ag}-\mathrm{Cu}-\mathrm{Ti}$ alloy $(5 \mathrm{~mm} \times 3 \mathrm{~mm} \times 4-5.5 \mathrm{~mm}, 0.6-0.82 \mathrm{~g}$ ) were prepared by coldpressing (270 MPa) commercial powders of silver (99,99 wt.\% pure, Goodfellow), copper (99 wt.\% pure, Goodfellow) and titanium (purity higher than $98 \mathrm{wt} \%$, grain size after sieving $\mathrm{d}<100 \mu \mathrm{m}$, Merck). The blocks were put on a freshly polished and degreased titanium plate $\left(10 \mathrm{~mm} \times 5 \mathrm{~mm} \times 2 \mathrm{~mm}\right.$ ) that was entirely coated with a $\mathrm{Y}_{2} \mathrm{O}_{3}$-based oxide liner (Stopyt, Morgan), except for a square area of $2 \mathrm{~mm} \times 2 \mathrm{~mm}$ at its upper face that remained uncovered and was thus in direct contact with the $\mathrm{Ag}-\mathrm{Cu}(-\mathrm{Ti})$ alloy. The samples were put in an alumina boat and placed inside a silica reaction tube evacuated under a dynamic primary vacuum of $\sim 1$ $\mathrm{Pa}$. Another boat filled with titanium powder was also placed in the hot zone of the reaction tube to act as a getter protecting the samples from oxidation, nitridation or carburization. The reaction tube was heated using a horizontal tubular furnace regulated to better than $\pm 1{ }^{\circ} \mathrm{C}$. The temperature was first raised in less than $30 \mathrm{~min}$ from $25^{\circ} \mathrm{C}$ to $790{ }^{\circ} \mathrm{C}$ and then held at that value for durations varying from 2 to $50 \mathrm{~min}$. At the end of the isothermal heat-treatment, the samples were cooled to room temperature by pulling the silica reaction tube out of the furnace. The mean cooling rate during the first $100{ }^{\circ} \mathrm{C}$ drop was faster than $10{ }^{\circ} \mathrm{C} \mathrm{s}^{-1}$.

The heat-treated samples were diamond sawn, polished and examined by optical metallography $(\mathrm{OM})$ and field-emission gun scanning electron microscopy (FEG-SEM, Hitachi S-800). Analyses were carried out by electron probe microanalysis (EPMA, Cameca Camebax) with an accelerating voltage of $10 \mathrm{kV}$ and a beam current of $9 \mathrm{nA}$ : under these conditions the lateral resolution was of $\pm 0.7 \mu \mathrm{m}$. After background subtraction, the counting rates obtained for $\mathrm{Ag}, \mathrm{Cu}$ and $\mathrm{Ti}$ in at least ten different points of the same layer or type of crystals were averaged and referred to the counting rates recorded under the same conditions on pure and freshly polished element standards. After corrections for atomic number, absorption and fluorescence, the atomic contents of $\mathrm{Ag}, \mathrm{Cu}$ and $\mathrm{Ti}$ were obtained with an accuracy better than \pm 0.5 at $\%$. It had been previously verified by X-ray powder diffraction [7] that the crystalline phases for which each interface reaction layer or crystal analysed were effectively obtained under the same heat-treatment conditions.

\section{Results}

Depending on whether the $\mathrm{Ag}-\mathrm{Cu}$ alloy was saturated in titanium or not, the reaction zones formed between solid titanium and the liquid alloy varied in thickness, morphology and composition.

\section{1. Ag-40 at. \% Cu liquid saturated in Ti}

When titanium reacted at $790{ }^{\circ} \mathrm{C}$ with Ti-saturated $\mathrm{Ag}-\mathrm{Cu}$ eutectic alloy, a thick reaction zone rapidly developed at the liquid/solid interface. After $2 \mathrm{~min}$ at $790{ }^{\circ} \mathrm{C}$, the reaction zone had a total thickness of about $15 \mu \mathrm{m}$. After 15 and $50 \mathrm{~min}$ at that temperature, the reaction zone thickness attained $\sim 100 \mu \mathrm{m}$ and $\sim 150 \mu \mathrm{m}$, respectively. For the latter two reaction times, the reaction zone morphology was the same. As shown in Fig. 1, five successive layers can be distinguished between the unconverted titanium substrate and the solidified $\mathrm{Ag}-\mathrm{Cu}$ liquid saturated in Ti. 

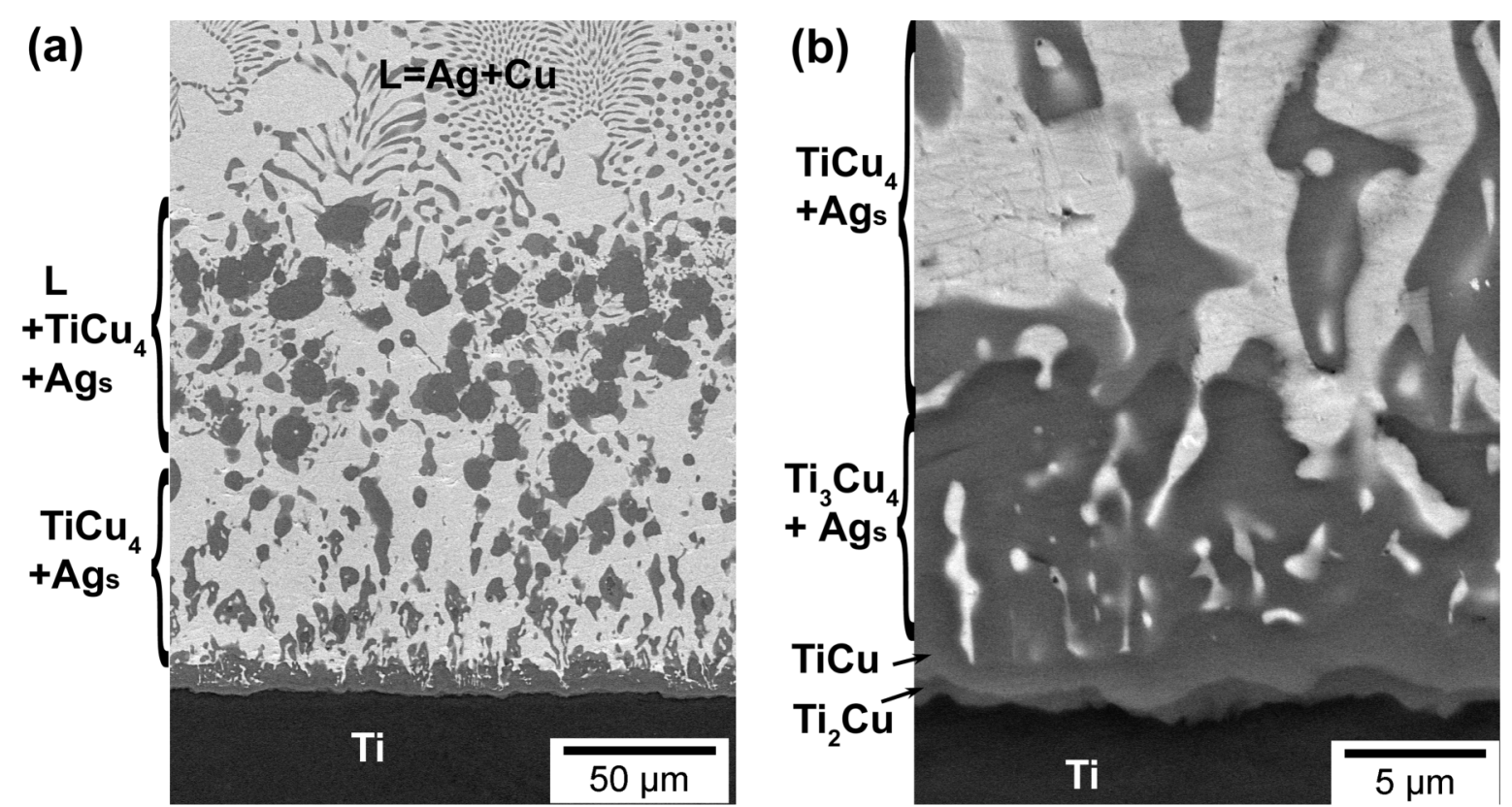

Fig. 1. Thick reaction zone formed between solid $\mathrm{Ti}$ and liquid $\mathrm{Ag}-40$ at.\% $\mathrm{Cu}$ alloy saturated in $\mathrm{Ti}\left(1.88\right.$ at.\% Ti) after $50 \mathrm{~min}$ of heating at $790{ }^{\circ} \mathrm{C}$ : (a) general view; (b) zoom near the Ti surface

In direct contact with titanium, a first thin layer (less than $2 \mu \mathrm{m}$ thick) with a single-phased appearance has formed. According to its EPMA analysis (Table 1), this first layer consists of the phase $\mathrm{Ti}_{2} \mathrm{Cu}$ with some silver in solid solution. A second layer (less than $3 \mu \mathrm{m}$ thick) surrounding the first one also exhibits a single-phased appearance: it analyzes by EPMA (Table 1) for the compound $\mathrm{TiCu}$ with some silver in solid solution. A third layer which is thicker than the two previous ones (about $10 \mu \mathrm{m}$ thick) and which clearly consists of two different phases can then be observed: in that layer, the dark phase analyzes for $\mathrm{Ti}_{3} \mathrm{Cu}_{4}$ whereas the bright inclusions are made of metallic silver with about 9 at $\%$ of copper and 5 at $\%$ of titanium dissolved (Table 1). The fourth layer rapidly contains more bright phase than the third so that the bright phase becomes a matrix which embeds dark elongated crystals. According to EPMA (Table 1), the bright phase consists of metallic silver with 9-14 at.\% of copper and 5-1 at.\% of titanium dissolved and the dark phase is made of $\mathrm{TiCu}_{4}$. Finally, a thick transition zone with non-defined borders can be seen between the fourth $\mathrm{TiCu}_{4}+\mathrm{Ag}_{\mathrm{s}}$ layer and the free solidified $\mathrm{Ag}-\mathrm{Cu}(\mathrm{Ti})$ alloy. According to SEM, OM and EPMA, three phases were present at $790{ }^{\circ} \mathrm{C}$ in this transition zone: nearly eutectic $\mathrm{Ag}-\mathrm{Cu}(\mathrm{Ti})$ alloy, a solid silver-rich phase and globular $\mathrm{TiCu}_{4}$ crystals. The reaction layer sequence taking all these features into account can be expressed as:

$$
\alpha \mathrm{Ti} / \mathrm{Ti}_{2} \mathrm{Cu} / \mathrm{TiCu} / \mathrm{Ti}_{3} \mathrm{Cu}_{4}+\mathrm{Ag}_{\mathrm{s}} / \mathrm{TiCu}_{4}+\mathrm{Ag}_{\mathrm{s}} / \mathrm{TiCu}_{4}+\mathrm{Ag}_{\mathrm{s}}+\mathrm{L} / \mathrm{L},
$$

where $\mathrm{L}$ designates a $\mathrm{Ag}_{\mathrm{s}}+\mathrm{Cu}_{\mathrm{s}}$ nearly eutectic mixture resulting from the solidification of the liquid $\mathrm{Ag}-\mathrm{Cu}(\mathrm{Ti})$ alloy $\left(\mathrm{Cu}_{\mathrm{s}}\right.$ and $\mathrm{TiCu}_{4}$ phases cannot be distinguished by SEM in Fig. 1 but are easily identifiable by their colour when observed by OM). It is to note that in the Ag-CuTi system, no ternary eutectic transformation exists involving the four phases $\mathrm{Ag}_{\mathrm{s}}, \mathrm{Cu}_{\mathrm{s}}, \mathrm{TiCu}_{4}$ and $\mathrm{L}$. Instead, the liquid $\mathrm{L}$ reacts with $\mathrm{TiCu}_{4}$ below $783{ }^{\circ} \mathrm{C}$ (transitory ternary peritectic reaction) to give solid copper and solid silver. This is the reason why although the liquid $\mathrm{L}$ is saturated in $\mathrm{Ti}$, no $\mathrm{TiCu}_{4}$ crystal precipitates up to complete solidification at $780{ }^{\circ} \mathrm{C}$. 
Table 1. Ag, $\mathrm{Cu}$ and $\mathrm{Ti}$ contents found by EPMA in the reaction layers formed after $50 \mathrm{~min}$ at $790{ }^{\circ} \mathrm{C}$ between solid titanium and Ti-saturated $\mathrm{Ag}-40 \mathrm{at} . \% \mathrm{Cu}$ liquid alloy

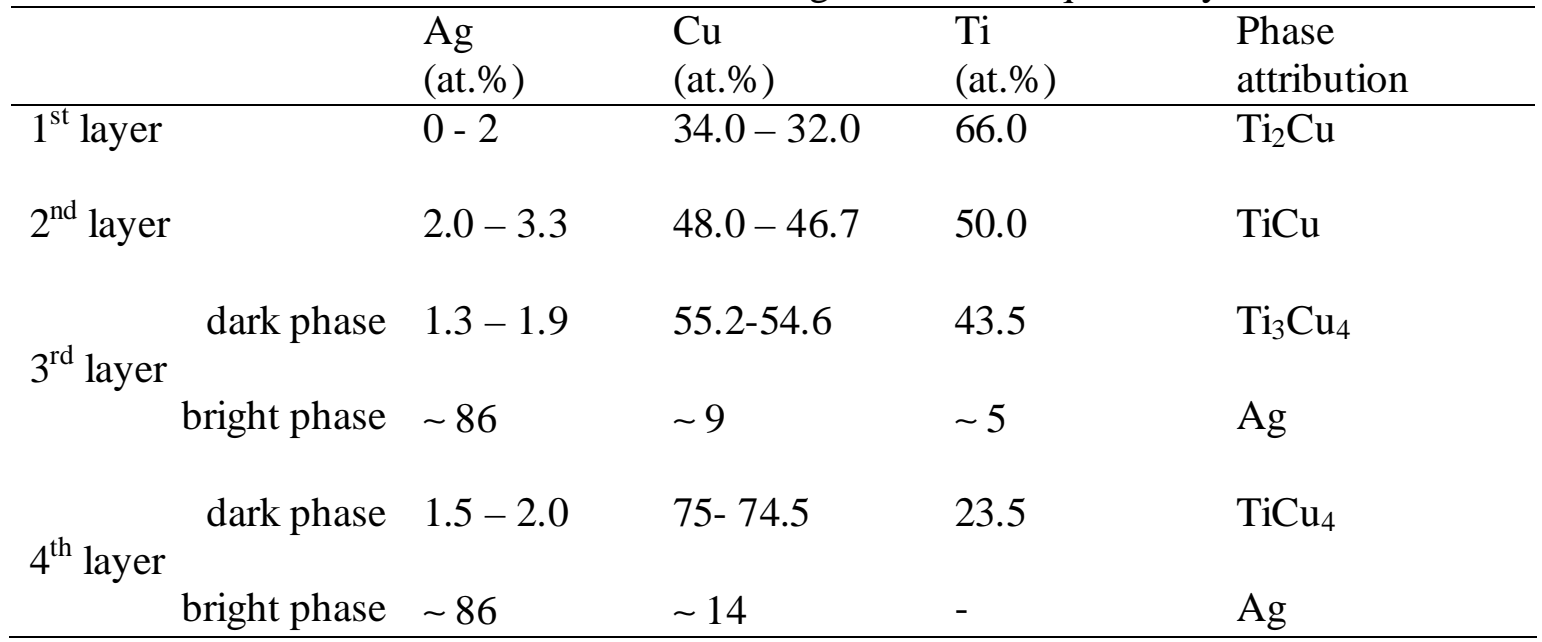

\section{2. Ag-40 at.\% Cu liquid without Ti}

When no titanium was initially present in the $\mathrm{Ag}-\mathrm{Cu}$ alloy, the major phenomenon seen was the dissolution of that element in the liquid alloy. After $50 \mathrm{~min}$ of heating at $790{ }^{\circ} \mathrm{C}$, a depression with a depth attaining $60 \mu \mathrm{m}$ was observable at the surface of the titanium plate, where a direct contact with the liquid alloy was established. Taking into account the area of the exposed surface $(2 \mathrm{~mm} \times 2 \mathrm{~mm})$ and the volume of the liquid $\left(\sim 80 \mathrm{~mm}^{3}\right)$, the increase of the Ti content in the drop was estimated to be about 0.2 at.\%, which is only a tenth of the saturation value at $790{ }^{\circ} \mathrm{C}$. Regardless of the heat-treatment time (from $2 \mathrm{~min}$ to $50 \mathrm{~min}$ ), the reaction zone formed under these conditions at the liquid/solid interface remained very thin: its total thickness was in the range 3-6 $\mu \mathrm{m}$. Fig. 2 shows that this zone consists of four different layers. Each of them is dense, continuous and exhibits a single-phased appearance, apart from some rare places in the outer layer where silver-rich inclusions are observable. The counting rates obtained for $\mathrm{Ag}, \mathrm{Cu}$ and $\mathrm{Ti}$ by EPMA in the thickest parts of each layer were characteristic for single-phased compounds arranged according to the reaction layer sequence:

\section{$\alpha \mathrm{Ti} / \mathrm{Ti}_{2} \mathrm{Cu} / \mathrm{TiCu} / \mathrm{Ti}_{3} \mathrm{Cu}_{4} / \mathrm{TiCu}_{4} / \mathrm{L}^{\prime}$,}

where L' designates a $\mathrm{Ag}_{\mathrm{s}}+\mathrm{Cu}_{\mathrm{s}}$ mixture resulting from the solidification of the liquid alloy.

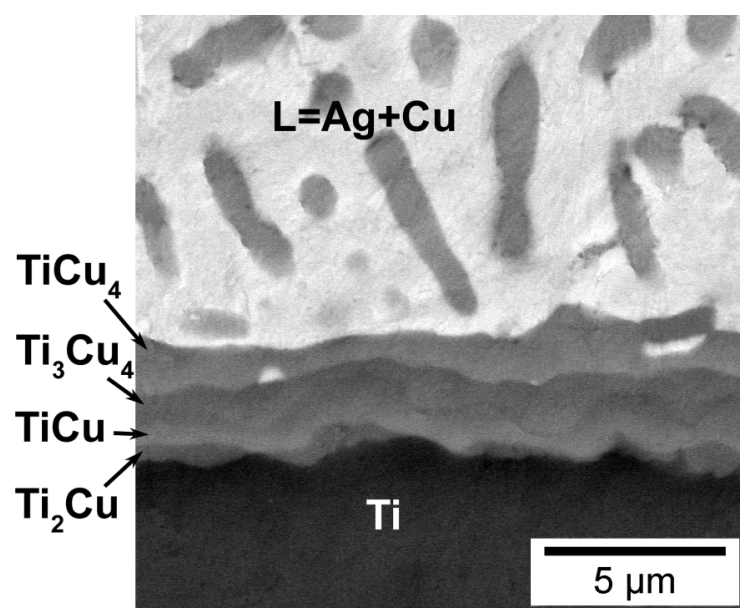

Fig. 2. Thin reaction zone formed between solid $\mathrm{Ti}$ and titanium-free $\mathrm{Ag}-40$ at.\% $\mathrm{Cu}$ liquid alloy after $50 \mathrm{~min}$ of heating at $790{ }^{\circ} \mathrm{C}$ 


\section{3. Reaction layer sequences and phase equilibria}

Fig. 3 shows the isothermal section of the $\mathrm{Ag}-\mathrm{Cu}-\mathrm{Ti}$ phase diagram at $790{ }^{\circ} \mathrm{C}$, calculated with the Thermo-calc software by using the already developed thermodynamic descriptions of the $\mathrm{Ag}-\mathrm{Cu}$ [9], Ag-Ti [10] and $\mathrm{Cu}-\mathrm{Ti}$ [11] binaries. Extension to the third-order $\mathrm{Ag}-\mathrm{Cu}-\mathrm{Ti}$ system was made by using the assessment by Arroyave [12]. In this section, which is in good agreement with previous literature data [8, 13-15], two reaction paths have been drawn to represent each of the two layer sequences. Both reaction paths comply with the mass balance, provided that the liquid is slightly enriched in Ag near the liquid/solid interface. For both sequences, it has moreover been verified by using the Thermo-Calc software that the activities of $\mathrm{Ti}$ and $\mathrm{Cu}$ regularly decrease and increase, respectively, when moving through the reaction zone from $\mathrm{Ti}$ to the liquid alloy as shown in Fig. 4. Accordingly, $\mathrm{Ti}$ and $\mathrm{Cu}$ atoms can intrinsically diffuse in opposite directions down their activity gradient [16]. Finally, local phase equilibria are established at all interfaces [17], except at the $\mathrm{Ti}_{3} \mathrm{Cu}_{4} / \mathrm{TiCu}_{4}$ interface where the stable compound $\mathrm{Ti}_{2} \mathrm{Cu}_{3}$ should be present. In fact, it has been shown in previous work that in the solid state, $\mathrm{Ti}_{2} \mathrm{Cu}_{3}$ grows at a much slower rate than $\mathrm{TiCu}_{4}$ and $\mathrm{Ti}_{3} \mathrm{Cu}_{4}$ [7]. The two reaction paths drawn in Fig. 3 can thus be considered as diffusion paths, it being understood that due to a very slow rate of growth, the compound $\mathrm{Ti}_{2} \mathrm{Cu}_{3}$ is transiently "missing".

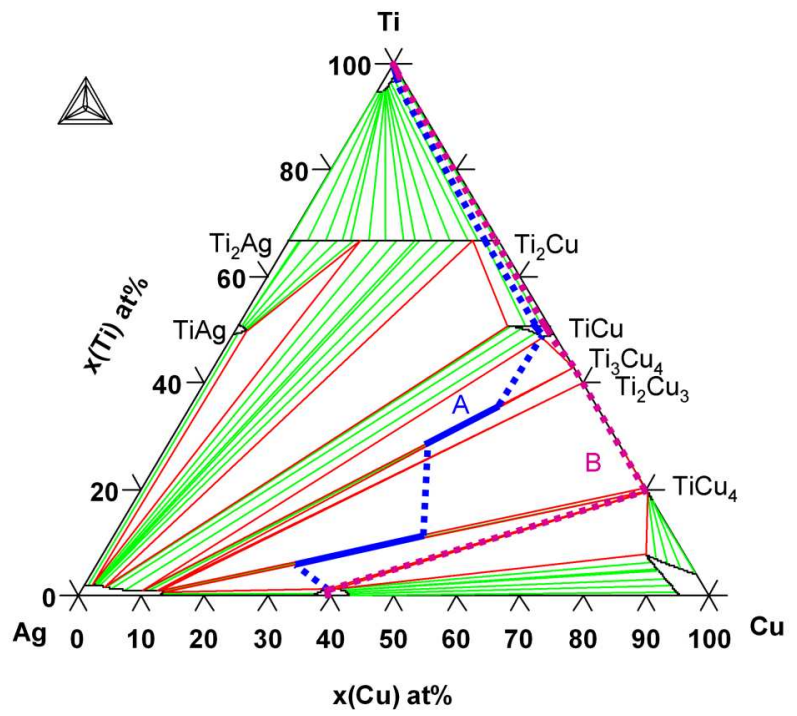

Fig. 3. The Ag-Cu-Ti ternary phase diagram as calculated at $790{ }^{\circ} \mathrm{C}$. Two diffusion paths have been drawn corresponding to the reaction zones formed in Ag-40 at.\% $\mathrm{Cu}$ alloys saturated in $\mathrm{Ti}$ (path A) and without Ti (path B)

\section{Discussion}

Formation of the $\mathrm{Ti} / \mathrm{Ag}-\mathrm{Cu}$ reaction zones of the second type (Fig. 2) can be described as follows. As soon as the eutectic $\mathrm{Ag}$-Cu alloy melts (M.P. $780^{\circ} \mathrm{C}$ ), the Ti base metal begins to dissolve in the liquid. When the Ti activity in the liquid is sufficiently high near the Ti surface, the compound $\mathrm{TiCu}_{4}$ nucleates on $\mathrm{Ti}$ and rapidly forms a continuous reaction layer of small crystals that isolates $\mathrm{Ti}$ from the liquid as previously reported [7]. Other $\mathrm{Ti}-\mathrm{Cu}$ compounds can then nucleate and grow by solid state reaction-diffusion between $\mathrm{Ti}$ and the $\mathrm{TiCu}_{4}$ layer. A reaction zone is thus formed (Fig. 4a), consisting of four dense and singlephased layers of compounds arranged according to the diffusion path B in the Ag-Cu-Ti phase diagram (Fig. 3). Obviously, the four layers tend to grow by solid state volume diffusion. 


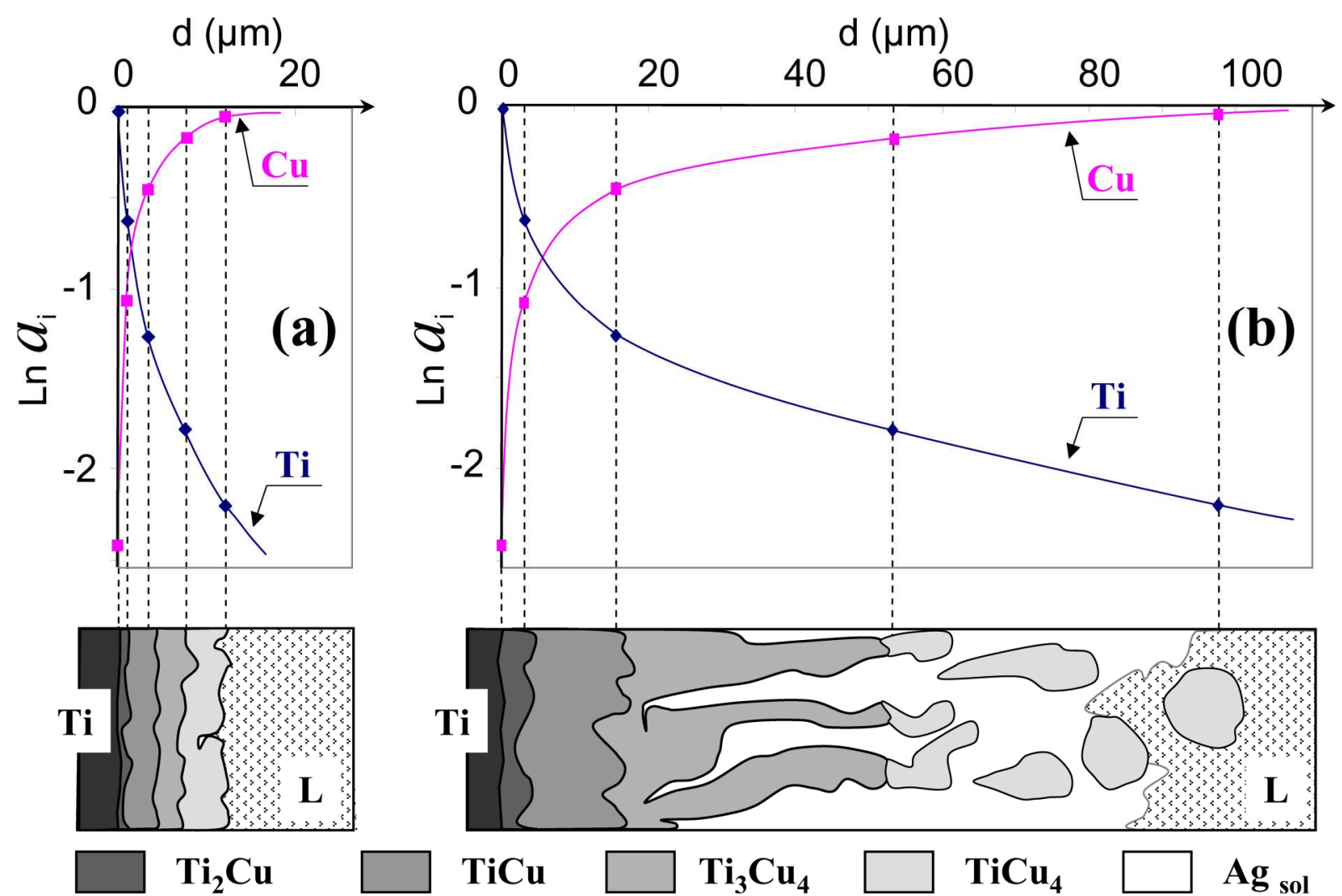

Fig. 4. Chemical activities of fcc-Cu and cph-Ti in the intermetallic compound layers formed by reaction at $790{ }^{\circ} \mathrm{C}$ of solid titanium with (a) pure and (b) Ti-saturated $\mathrm{Ag}-40$ at.\% Cu liquid alloy

However, at the same time, titanium is dissolved in the liquid $\mathrm{Ag}-\mathrm{Cu}$ alloy which is far from being saturated in titanium. In such an instance where growth by solid state diffusion and dissolution are competing, the reaction zone rapidly attains a constant thickness, as described in detail by Dibkov [18]. This explains why, although growing by solid state diffusion, the reaction zone does not increase in thickness. As a consequence, the $\mathrm{Ti}$ and $\mathrm{Cu}$ chemical activity gradients through the reaction zone remain steep (Fig. 4a), which might be the key for keeping up nearly planar interfaces.

When the $\mathrm{Ag}-\mathrm{Cu}$ liquid is fully saturated in titanium, dissolution of this element does not proceed and the different layers of the interface reaction zone can grow according to two main processes: solid state diffusion of $\mathrm{Ti}$ and $\mathrm{Cu}$ atoms for all layers and precipitation from a liquid locally over-saturated in $\mathrm{Ti}$ for the $\mathrm{TiCu}_{4}$ crystals of the outer layer. As $\mathrm{TiCu}_{4}$ precipitation proceeds at a fast rate, the liquid in contact with the outer layer is depleted in copper. This gives rise to the formation of some solid silver grains. Then, new $\mathrm{TiCu}_{4}$ crystals precipitate on these grains from the liquid and new silver grains appear. Finally, a thick outer layer consisting of $\mathrm{TiCu}_{4}$ crystals embedded in a solid silver-based matrix is formed after a few minutes of reaction at $790{ }^{\circ} \mathrm{C}$. At this point, further precipitation of $\mathrm{TiCu}_{4}$ and of silverrich grains implies the solid state diffusion of titanium through the growing reaction layers. Accordingly, as the thickness of the reaction layers increases, the rates of precipitation of $\mathrm{TiCu}_{4}$ and $\mathrm{Ag}$ decrease. This would explain why the size and shape of the $\mathrm{TiCu}_{4}$ crystals (and also of the silver-rich grains) gradually change from small and elongated to larger and more globular. As the thickness of the reaction zone continues to increase, another process, implying long-range crossed diffusion of $\mathrm{Cu}$ and $\mathrm{Ti}$ in the solid state, takes place. This process is the chemical conversion of the oldest $\mathrm{TiCu}_{4}$ particles present in the inner part of the reaction zone into $\mathrm{Ti}_{3} \mathrm{Cu}_{4}$. Development of these different processes gives the liquid-solid 
reaction zone the morphological features schemed in Fig. 4b. It should be noted that, because of the saturation of the liquid in $\mathrm{Ti}$ and also of the large thickness of the two outer layers, the chemical activity gradients for $\mathrm{Ti}$ and $\mathrm{Cu}$ at the solid-liquid interface tend to be flat (Fig. $4 \mathrm{~b}$ ). This might be a reason why the solid/liquid boundary is not well-defined.

Let us now consider the formation of joints when Ti plates are brazed at $780-800{ }^{\circ} \mathrm{C}$ with $\mathrm{Ag}$ 40 at. $\% \mathrm{Cu}$ alloy. For that purpose, $50-100 \mu \mathrm{m}$ thick $\mathrm{Ag}-\mathrm{Cu}$ ribbons are generally used, which means that solid titanium in excess reacts with a limited amount of $\mathrm{Ag}-\mathrm{Cu}$. The liquid alloy is thus rapidly saturated in $\mathrm{Ti}$ and the Ti/alloy reaction zone rapidly changes from type 2 to type 1. Fig. 5 shows a Ti/Ag-40 at. $\% \mathrm{Cu} / \mathrm{Ti}$ joint brazed at $790{ }^{\circ} \mathrm{C}$ for a short period of time (3 min) with an $\mathrm{Ag}-\mathrm{Cu}$ ribbon. The particular morphology of this joint is the result of a time sequence of four of the above-described processes, namely $\mathrm{Ti}$ dissolution, growth by solid state interdiffusion, fast rate precipitation of $\mathrm{TiCu}_{4}$, and isothermal solidification of $\mathrm{Ag}$. It is worth emphasizing that the four processes develop at a fast rate. Indeed, isothermal solidification of the braze alloy is completed after only $3 \mathrm{~min}$ of brazing. This implies fast rate migration of titanium and copper through solid silver. For lattice diffusion of $\mathrm{Ti}$ in solid $\mathrm{Ag}$ at $790{ }^{\circ} \mathrm{C}$, a diffusivity of the order of $1.510^{-9} \mathrm{~cm}^{2} \mathrm{~s}^{-1}$ is reported $[19,20]$. This value is too low to account for an isothermal solidification of the joint in less than $3 \mathrm{~min}$. On the other hand, a diffusivity of the order of $510^{-6} \mathrm{~cm}^{2} \mathrm{~s}^{-1}$ is reported for grain boundary diffusion of $\mathrm{Ti}$ in $\mathrm{Ag}$ at $790{ }^{\circ} \mathrm{C}$ [20]. Such a high grain boundary diffusivity is consistent with the fast rate isothermal solidification observed, and this all the more than silver grains tend to grow in the form of joining columns (Fig. 5). The fact that a silver-rich zone without $\mathrm{TiCu}_{4}$ crystals exists in the central part of the joint would indicate that $\mathrm{Cu}$ diffuses slightly faster than $\mathrm{Ti}$. Upon further annealing (up to 15 hours) at $790{ }^{\circ} \mathrm{C}$, the crystals of $\mathrm{TiCu}_{4}$ embedded in the Ag-based matrix will be slowly converted by solid state reaction-diffusion first into $\mathrm{Ti}_{3} \mathrm{Cu}_{4}$ and then into $\mathrm{TiCu}$. This will increase the re-melting temperature of the brazed joint step by step from 780 to about $910{ }^{\circ} \mathrm{C}[21]$.

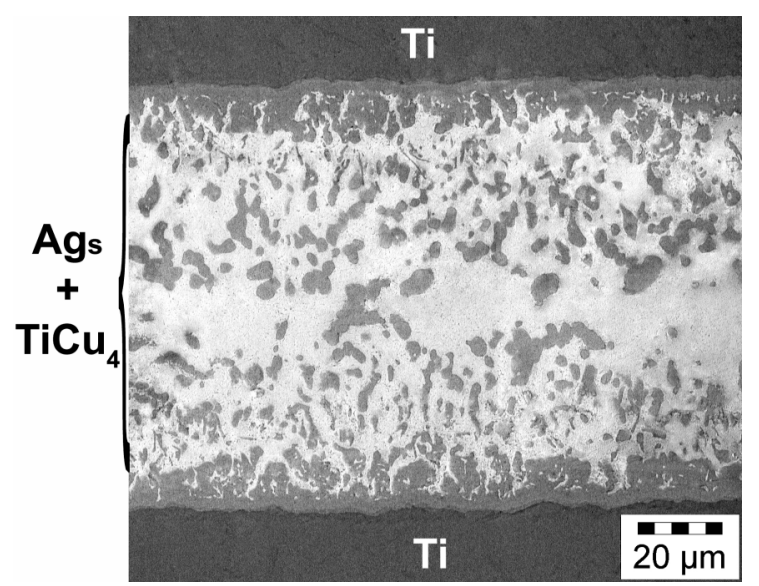

Fig. 5. Ti/Ag-40 at.\% Cu / Ti sandwich joint after 3 min of brazing at $790{ }^{\circ} \mathrm{C}$

\section{Conclusion}

Interface reaction zones of two different types are formed by chemical interaction at 780$800{ }^{\circ} \mathrm{C}$ between solid titanium and liquid $\mathrm{Ag}-40$ at.\% $\mathrm{Cu}$ eutectic alloy:

- as long as titanium is in contact with a pure $\mathrm{Ag}-\mathrm{Cu}$ alloy, a thin reaction zone $(3-6 \mu \mathrm{m}$ in thickness) is present at the liquid/ solid interface. This zone consists of four continuous layers arranged according to the sequence $\alpha \mathrm{Ti} / \mathrm{Ti}_{2} \mathrm{Cu} / \mathrm{TiCu} / \mathrm{Ti}_{3} \mathrm{Cu}_{4} / \mathrm{TiCu}_{4} / \mathrm{L}$. The layer sequence is consistent with a solid state growth process, with $\mathrm{Ti}$ and $\mathrm{Cu}$ diffusing down their 
activity gradients. The fact that the reaction zone thickness does not change when the reaction time increases is explained by the fast dissolution rate of titanium in the liquid alloy;

- when the $\mathrm{Ag}-\mathrm{Cu}$ alloy is saturated in titanium (about 1.88 at. $\%$ Ti at $790{ }^{\circ} \mathrm{C}$ ), dissolution no longer proceeds and a reaction zone is formed with a thickness increasing with the reaction time. In that case, the reaction layer sequence is: $\alpha \mathrm{Ti} / \mathrm{Ti}{ }_{2} \mathrm{Cu} / \mathrm{TiCu} / \mathrm{Ti}_{3} \mathrm{Cu}_{4}+\mathrm{Ag}_{\mathrm{s}} /$ $\mathrm{TiCu}_{4}+\mathrm{Ag}_{\mathrm{s}} / \mathrm{TiCu}_{4}+\mathrm{Ag}_{\mathrm{s}}+\mathrm{L} / \mathrm{L}$. In addition to $\mathrm{Ti}$ dissolution and $\mathrm{Ti}-\mathrm{Cu}$ solid state interdiffusion, three other elementary reaction processes are identified. These are the nucleation and growth from the liquid of $\mathrm{TiCu}_{4}$ particles, the isothermal solidification of silver, and the chemical conversion of $\mathrm{Cu}-\mathrm{Ti}$ compounds by reaction-diffusion in the solid state. A time sequence of these five elementary reaction processes is finally proposed to account for the morphology and composition of Ti/ $\mathrm{Ag}-\mathrm{Cu} / \mathrm{Ti}$ joints brazed at $780-800{ }^{\circ} \mathrm{C}$.

\section{References}

1. N. Eustathopoulos, M.G. Nicholas and B. Drevet, Wettability at High Temperature, Pergamon, Amsterdam (NL), 1999, p 348-384

2. M. F. Wu, Z. S. Yu, C. Y. Jiang, C. Liang, Growth Mechanism of Compounds at the Interface of Ti6A14V/Ag-28Cu Filler Alloy, Mater. Sci. Technol., 2002, 18, p 1314-1316 3. R.K. Shiue, S.K. Wu, C.H. Chan, Interfacial Reactions of IR Brazing $\mathrm{Cu}$ and Ti, J. Alloys Compd., 2004, 372, p 148-157

4. C.C. Liu, C.L. Ou, R.K. Shiue, The Microstructural Observation and Wettability Study of Brazing Ti-6Al-4V and 304 Stainless Steel Using Three braze Alloys, J. Mater. Sci., 2002, 37, p 2225-2235

5. W.D. MacDonald, T.W. Eagar, Transient liquid Phase Bonding, Annual Review of Materials Science, 1992, 22, p 23-46

6. W.D. MacDonald, T.W. Eagar, Low Temperature Transient Liquid Phase Bonding of Ti6Al-4V, International Trends in Welding Science and Technology, Proceedings of the $3^{\text {rd }}$ International Conference on Trends in Welding Research, Gattinburg (TN-USA), June 1-5 1992, S.A. David and J.M. Vitek eds., ASM Int., Metal Park, 1992, p 1083-1087

7. J. Andrieux, O. Dezellus, F. Bosselet, M. Sacerdote-Peronnet, C. Sigala, R. Chiriac, J.C. Viala, Details on the Formation of $\mathrm{Ti}_{2} \mathrm{Cu}_{3}$ in the Ag-Cu-Ti System in the Temperature Range 790 to $860^{\circ} \mathrm{C}, J$. Phase Equilibria and Diffusion, 2008, 29, p 156-162

8. V.N. Eremenko, Y.I. Buyanov, N.M. Panchenko, The liquidus Surface of the System Ti$\mathrm{Cu}-\mathrm{Ag}$, Porosh Metall., 1970, 88, p 44-48

9. U.R. Kattner, Phase Diagrams for Lead-free Solder Alloys, JOM, 2002, 54, p 45-51

10. M. Li, C. Li, F. Wang, W. Zhang, Experimental Study and Thermodynamic Assessment of the Ag-Ti System, CALPHAD, 2005, 29, p 269-275

11. K.C.H. Kumar, I. Ansara, P. Wollants, L Delaey, Thermodynamic Optimisation of the Cu-Ti System, Z. Metallkunde, 1996, 87, p 666-672

12. R. Arroyave, "Thermodynamics and Kinetics of Ceramic/Metal Interfacial Interactions", Phil Doc Thesis, MIT (USA), 2004

13. O. Kubaschewski in Ternary Alloys, Vol. 2, G. Petzow, G. Effenberg eds.,VCH, Weinheim (G), 1988, p 55-59

14. P. Villars, A. Prince, H. Okamoto, Handbook of Ternary Alloy Phase Diagrams, ASM Int., Metals Park, 1995, p 2353-2360

15. Ag-Cu-Ti (Silver-Copper-Titanium), Non-Ferrous Metal Ternary Systems. Selected Soldering and Brazing Systems: Phase Diagrams, Crystallographic and Thermodynamic Data, Landolt-Börnstein - Group IV Physical Chemistry, Volume 11C3, Non-Ferrous Metal Systems, Part 3, Springer Berlin Heidelberg, 2007, pp 63-74 
16. F.J.J. van Loo, Multiphase Diffusion in Binary and Ternary Solid-State Systems, Progr. Solid State Chem., 1990, 20, p 47-99

17. H. Yokokawa, Generalized Chemical Potential Diagram and Its Applications to Chemical Reactions at Interfaces between Dissimilar Materials, J. Phase Equilibria, 1999, 20, p 258287

18. V.I. Dibkov, Growth Kinetics of Chemical Compound Layers, Cambridge Int. Sci. Pub, Cambridge (UK), 1998

19. G. Neumann, V. Tolle, C. Tuijn, Application of the Modified Electrostatic Model to Diffusion of Transition Metals in Noble Metals, Physica B, 2005, 363, p 7-18

20. Y. L. Zou, T. L. Alford, Y. Zeng, F. Deng, S. S. Lau, T. Laursen, A. I. Amali, B. M. Ullrich, Formation of Titanium Nitride by Annealing Ag/Ti Structures in Ammonia Ambient, J. Appl. Phys., 1997, 82, p 3321-3327

21. O. Dezellus, J. Andrieux, F. Bosselet, M. Sacerdote-Peronnet, T. Baffie, F. Hodaj, N. Eustathopoulos, J.C. Viala, Transient Liquid Phase Bonding of Titanium to Aluminium Nitride, Mater. Sci. Eng. A, 2008, xxx, xx (DOI: 10.1016/j.msea.2007.10.104). 